\author{
Russell R. King \\ Agriculture and Agri-Food Canada, Fredericton, Canada
}

\title{
PLANT PATHIOGENICITY IN THE GENUS STREPTOMYCES
}

Streptomyces species are novel plant pathogens in that they are filamentous prokaryotes. This genus is distinguished by the production of nonfragmenting substrate mycelium that colonizes and penetrates organic matter in the soil. Streptomyces use extracellular hydrolytic enzymes to gain nutrition from organic compounds that resist degradation by many other soildwelling microbes. Like many fungi that also have an immobile life style, Streptomyces species produce spores to aid their dispersal. Spore chains are produced through fragmentation of aerial hyphae that form on the substrate mycelium. The shape of the spore chains, which may be straight, branched, spiral, or wavy, is an important taxonomic characteristic (63). Streptomyces species have DNA with a high proportion of guanine and cytosine, and at least some species have been shown to possess a single linear chromosome (46).

Streptomyces species are well known for their ability to produce biologically active secondary metabolites, particularly antibiotics (17). These compounds likely improve the fitness of Streptomyces species in the highly competitive soil environment. Most of the pharmaceutically important antibiotics, such as streptomycin, are produced by Streptomyces species. At least one secondary metabolite, bialaphos, produced by Streptomyces hygroscopicus and $S$. viridochromogenes, has herbicidal properties. The biosynthetic genes for this compound have been cloned and characterized (53). Interestingly, only a very small proportion of the described Streptomyces species are known to be plant or animal pathogens.

Plant-pathogenic Streptomyces species cause diseases of underground structures of diverse plant species. Streptomyces scabies

Dr. Loria's address is: Department of Plant Pathology, Cornell University, Ithaca, NY 14853.

Publication no. D-1997-0606-01F

(C) 1997 The American Phytopathological Society
(41), a cause of common scab of potato and similar diseases of other plant species, was the first of these species described and is the best studied of the pathogenic species. Streptomyces acidiscabies (40) produces symptoms like those of $S$. scabies on potato (52) and on other taproot crops (39), although the two species are not closely related based on DNA-DNA homology (21). S. ipomoeae (57) causes soil rot of sweet potato, which is characterized by necrosis of fibrous roots and cankers on expanded storage roots. Several other Streptomyces species cause disease, although much less is known about these pathogens than about the three species mentioned previously. Unfortunately, there are many unsubstantiated reports in the literature of Streptomyces species causing diseases on crops. Descriptions of previously uncharacterized strains should be accompanied by information about the methods used for isolation and pathogenicity testing as well as documentation of symptoms. Consistency of morphological and physiological characteristics among a group of strains representing a new species and comparison to type cultures that have been used in other studies are also important to insure the reproducibility of results.

Among the diseases caused by Streptomyces species, potato scab is undoubtedly the most economically important. Potato scab was ranked as the fourth most important disease of this crop in North America based on a grower survey conducted in 1991 (65). More than 550,000 ha of potatoes are grown in the United States. Potato scab reduces the marketability of table stock, processing, and seed potato tubers because of the external symptoms and the tuber-borne nature of the pathogens. Most potato varieties grown in the United States are susceptible to scab (58). Scab diseases on other taproot crops are relatively minor problems in comparison. In contrast, $S$. ipomoeae causes significant economic losses by reducing the yields as well as the marketability of the storage roots of sweet potato (11). Until the introduction of resistant cultivars, soil rot was the limiting factor in sweet potato production in the United States (Christopher Clark, Louisiana State University, Baton Rouge, personal communication).

In this article, we discuss the biology and ecology of plant pathogenic Streptomyces species and the strategies used for management of the diseases they cause. We also consider the role of thaxtomins (44), a family of phytotoxins, in diseases caused by at least some plant-pathogenic Streptomyces species. Similarities in the effects of these toxins on plants and in the symptoms produced by the pathogens, as well as the correlation between pathogenicity and toxin production, suggest that these compounds are intimately involved in disease development. The effects of thaxtomins on plants and the possibility of a universal target for these toxins in plant cells is addressed. We conclude with a discussion of the questions remaining about plant pathogenicity in the genus Streptomyces, strategies for answering these questions, and the potential for improvements in disease management.

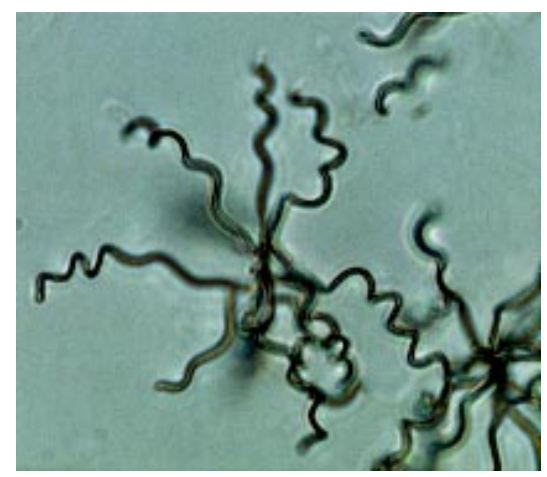

Fig. 1. Typical corkscrew spiral spore chains of Streptomyces scabies develop from aerial hyphae that arise from substrate mycelium. The colony was grown on water agar for 7 days at $28^{\circ} \mathrm{C}$. 

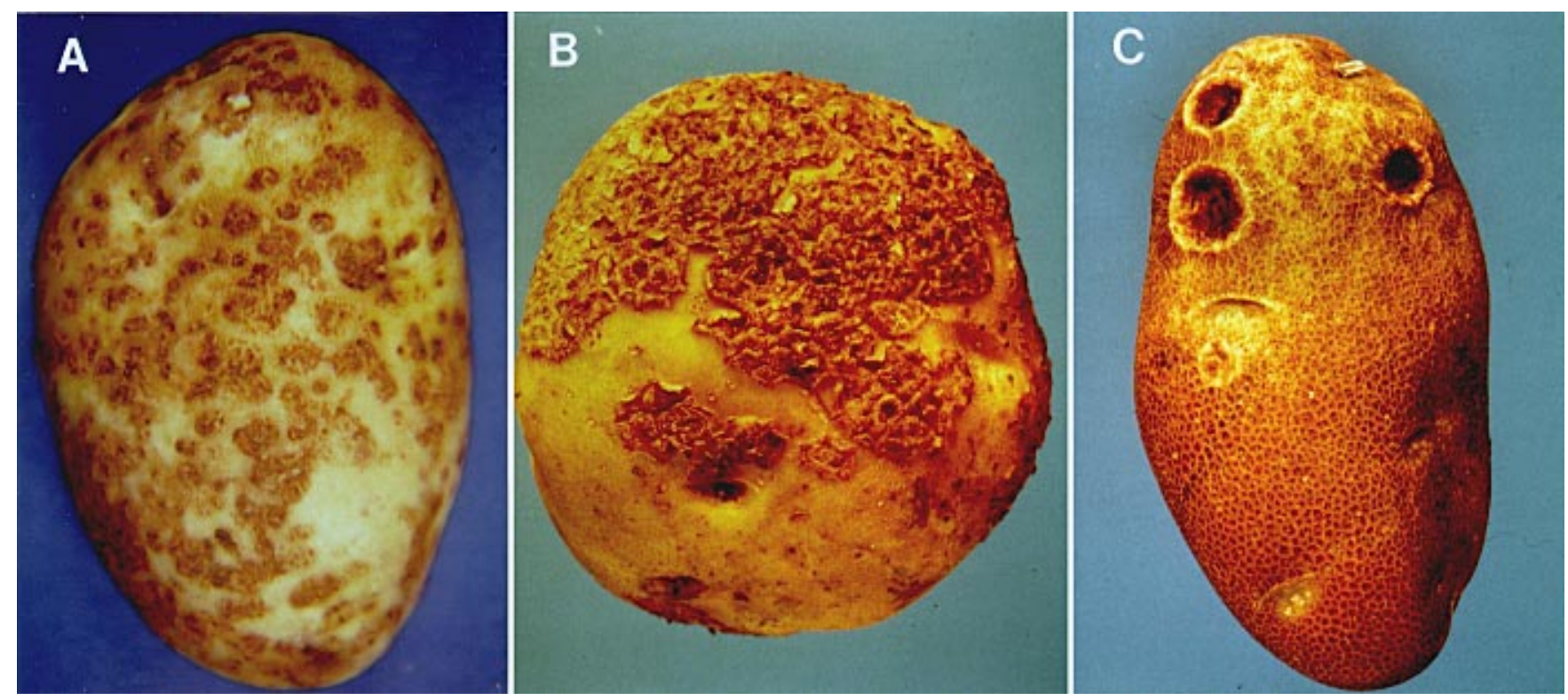

Fig. 2. Streptomyces scabies can produce a range of symptoms on potato tubers. (A) Superficial lesions are sometimes referred to as russet scab; these and similar symptoms also can be caused by several other Streptomyces species. (B) Raised lesions are usually referred to as common scab; however, these symptoms do not differ from those produced by S. acidiscabies. (C) Pitted lesions may or may not have a ridge of raised tissue surrounding the pit.

\section{Plant-Pathogenic Streptomyces and Diseases They Cause}

More than 400 Streptomyces species have been described, most of which are soil-dwelling saprophytes. Although relatively few in number, plant-pathogenic Streptomyces species actually infect a wide range of crop species. Streptomyces infection is limited to the underground plant parts, and necrosis is often the first symptom of these diseases. Systemic plant infection has never been reported, although aerial portions of plants can be stunted or wilted if root infection is severe.

Most research on plant pathogenic Streptomyces species has focused on diseases of potato. Unfortunately, the terminology used to describe these diseases has not been consistently applied. In this article, we will group potato tuber diseases into those that are typified by decidedly erumpent (raised) or pitted scab symptoms and those that are characteristically superficial. We believe that this distinction may be relevant to the mechanisms of pathogenicity employed by the causal organisms.

\section{Erumpent Potato Scab Diseases}

At least three species of Streptomyces cause erumpent lesions on potato tubers. Two of these, S. scabies and S. acidiscabies, are well known as potato pathogens. A third species has recently been described by researchers in Japan (67). Although the identity of this species is not yet determined, it is clearly distinct from $S$. scabies and $S$. acidiscabies based on physiological, morphological, and genetic criteria. Severe erumpent scab symptoms are often accompanied by pitting of the tuber surface.
Highly virulent strains of S. scabies can produce pitted symptoms, and as we will discuss subsequently, this symptom may be due to high levels of thaxtomin production.

S. scabies. In 1890, Thaxter (69) identified the causal agent of common scab and named it Oospora scabies. Pathogenic strains produced a soluble brown pigment (melanin) and gray spores borne in spiral chains. The type culture was not maintained, and the species was renamed Actinomyces scabies by Gussow (19) and then $S$. scabies by Waksman and Henrici (71). Because of erroneous designation of the type strain that was used in a large taxonomic study called the International Streptomyces Project (ISP), the species was considered invalid and was listed as species incertae sedis ("type strain not extant, many taxonomically different strains available"). The name $S$. scabies was recently revived, and neotype strains were identified based on research conducted in Europe (14) and the United States (41). Using both morphological and physiological characteristics, S. scabies forms a relatively homogeneous group. The current species description is consistent with that of Thaxter in that it is characterized by production of melanin and smooth gray spores borne in spiral chains (Fig. 1) and by utilization of the nine sugars used for characterization of Streptomyces species by the ISP. By default, most of the $S$. scabies strains that have been well characterized are pathogens. However, not all S. scabies strains are pathogenic, and this species appears to be closely related to strictly saprophytic species (21). Therefore, studying the population dynamics of pathogenic strains of this species is difficult.

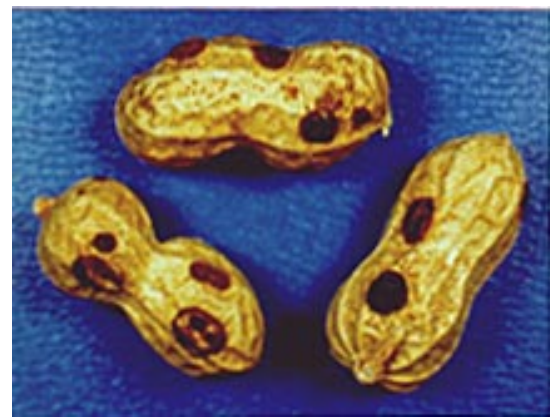

Fig. 3. Symptoms of pod wart of peanut caused by Streptomyces scabies in South Africa (courtesy A. DeKlerk and N. Mienie, Vegetable and Ornamental Plant Institute, Pretoria, South Africa).

S. scabies is the most important plant pathogen in the genus Streptomyces worldwide. This pathogen can cause superficial, erumpent, or pitted lesion types, but erumpent lesions are most common, and most lesions have a raised, rough, corky appearance (Fig. 2). S. scabies causes scab of potato in many countries in eastern and western Europe, South Africa, Australia, New Zealand, and Israel, as well as in the United States and Canada. This pathogen also incites scab of root crops such as radish, turnip, and carrot in some countries (23). Interestingly, S. scabies infects peanut, resulting in a disease called "pod wart of peanut" (36) that is characterized by raised, necrotic lesions on peanut hulls (Fig. 3) in South Africa (13). Other Streptomyces species may also cause this disease in Israel (36).

Because of its relative importance, almost all of the research conducted to date on the ecology and management of diseases caused by Streptomyces species has 

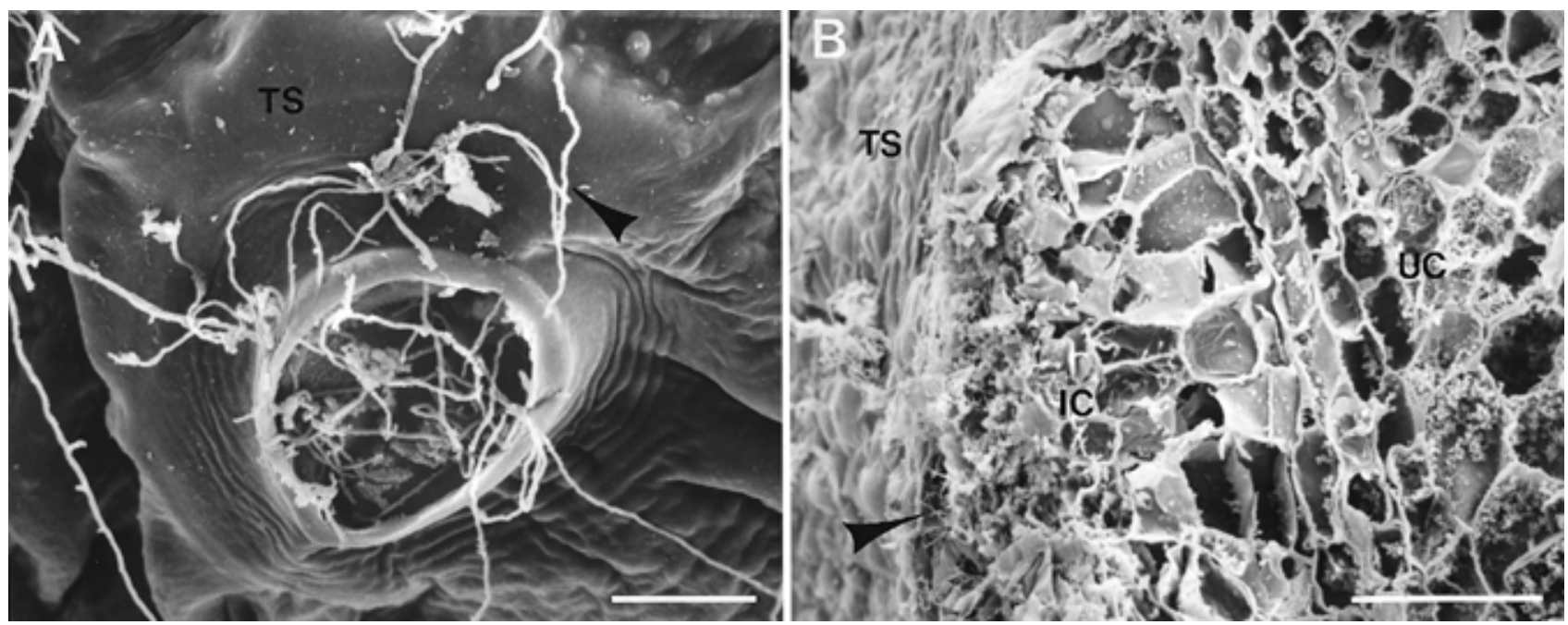

Fig. 4. Scanning electron micrographs depict the early stages of infection of immature potato tubers by Streptomyces scabies (courtesy B. Stein and R. Hammerschmidt, Michigan State University, E. Lansing). (A) Substrate hyphae (arrow) of S. scabies can colonize the tuber surface and penetrate the tuber through immature lenticels. Scale bar represents $10 \mu \mathrm{m}$. (B) Cross section of an immature potato tuber infected by $S$. scabies, showing the whole cells on the tuber surface (TS), infected outer cells (IC) containing mycelium, and uninfected cortex cells (UC). Scale bar represents $100 \mu \mathrm{m}$.
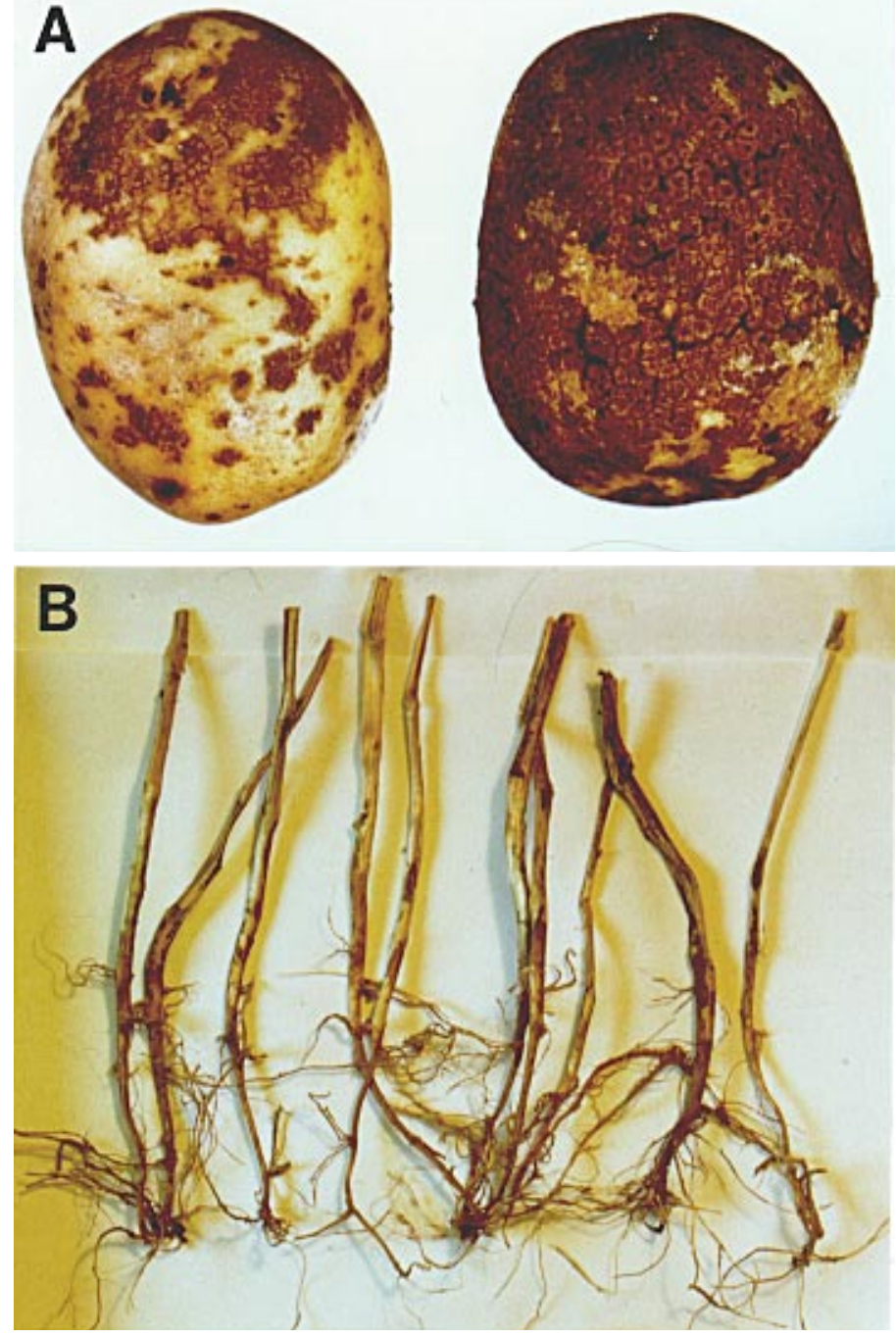

Fig. 5. Netted scab of potato is a problem in cool wet soils of several European countries (courtesy H. Bang, Institute for Plant Research and Cold Storage, Umea, Sweden). (A) Netted scab lesions on potato tubers appear as thickened, necrotic periderm that fractures in a netted pattern. (B) Infection of underground stems, stolons and roots by the Streptomyces species that cause netted scab results in tissue necrosis and yield loss. focused on S. scabies. The pathogen can be soil- or tuber-borne and is ubiquitous in potato production soils. This species appears to be adapted to the well-drained, near-neutral-pH soils in which potatoes and root crop vegetables are commonly grown. The optimum temperature for growth of S. scabies is $30^{\circ} \mathrm{C}$, consistent with observations of increased potato scab severity during growing seasons with higher than normal temperatures. S. scabies is inhibited at high soil moisture, which has led to the use of irrigation for disease control (42). Infection of potato tubers is primarily through immature lenticels (Fig. 4); therefore tubers are most susceptible to infection during the period of rapid tuber growth that commences when the tuber diameter reaches twice that of the stolon and continues for approximately 6 to 8 weeks. By maintaining high soil moisture during this period, effective disease control has been achieved in the United Kingdom. However, maintaining high soil moisture for such extended periods of time is impractical for many potato growers in North America.

Soil characteristics can greatly affect the severity of potato scab. Scab is most severe in soils with a pH of 5.2 to 7.0 (70). In some cases, scab control can be achieved by lowering the soil $\mathrm{pH}$ through the use of acid-producing fertilizers or applications of sulfur. Unfortunately, soils with $\mathrm{pH}$ values inhibitory to $S$. scabies are unfavorable for the growth of many agronomic and vegetable crops. Therefore, growers who maintain soil $\mathrm{pH}$ values below 5.2 to control scab limit their yields and rotational crop options. Animal manures have long been associated with increased severity of potato scab, although these effects are not well documented in the literature. Research on the mechanism by which animal manures affect Streptomyces species and potato scab 
is needed. Since animal manures are good sources of nitrogen and the use of manures in crop production systems is compatible with sustainable and organic crop production systems, the relationship between manure applications and potato scab merits further investigation.

Potato cultivars vary in their levels of scab resistance. However, there are very few highly resistant cultivars, and none are immune to the disease. Scab-resistant potato cultivars such as Russet Burbank and Superior can be severely affected by scab under conditions conducive to disease development. Although scab resistance is an objective of most, if not all, potato breeding programs (18), nothing is known about the nature of scab resistance, and very little is known about its inheritance.

Biological control of potato scab caused by $S$. scabies appears to hold great promise. Streptomyces strains antagonistic to this pathogen were originally isolated from tubers grown in a soil that became suppressive to scab after 23 years of potato monoculture (48). Antagonistic Streptomyces strains decreased scab severity and did not affect tuber yield in field plots (47). The mechanism of antagonism has not yet been demonstrated, but may involve antibiotic production.

S. acidiscabies. "Acid scab" was first reported to occur in Maine in 1953 (52). Symptoms were identical to those produced by $S$. scabies, but the disease occurred in soils with $\mathrm{pH}$ values as low as 4.5 , whereas common scab is controlled in soils with a $\mathrm{pH}$ of 5.0 or below. The causal organism was distinctly different from $S$. scabies based on morphological, physiological, and immunological attributes. The new pathogen was eventually named $S$. acidiscabies (40) and is characterized by production of white to pink spores borne in flexuous chains and a red or yellow $\mathrm{pH}$ sensitive diffusible pigment rather than melanin. The structure of this pigment, which has recently been described, suggests that it may have antibiotic properties (30). S. acidiscabies is unable to utilize raffinose as a sole carbon source and can grow at a $\mathrm{pH}$ of 4.0 in culture, compared with a minimum $\mathrm{pH}$ of 5.0 for $S$. scabies.

$S$. acidiscabies does not appear to survive in soil for long periods of time, as $S$. scabies can (52). Transmission of $S$. acidiscabies appears to be on infected or infested seed tubers, which suggests that this pathogen should be widely distributed. However, S. acidiscabies has only been confirmed to occur in the northeastern United States. S. acidiscabies can produce scab symptoms on taproot crops, as $S$. scabies can, but it has not been reported as a commercially important pathogen of these crops. Cultivars showing the highest resistance to infection by $S$. scabies also are most resistant to infection by $S$. acidiscabies (R. Loria, unpublished).

$S$. acidiscabies emerged as an economi- cally important pathogen when potatoes were repeatedly grown in low $\mathrm{pH}$ soils (52). During and prior to the 1940s, scabinfected tubers were treated with arsenic and used as seed. In the early 1950s, arsenic seed treatments were replaced with dithiocarbamate fungicides that are less toxic to Streptomyces species than is arsenic. At this point, acid scab became an economically important problem. Similarities in the potato cultivar response and host range of $S$. acidiscabies and $S$. scabies suggest a common mechanism of plant pathogenicity or disease resistance. Perhaps pathogenicity genes were transferred from $S$. scabies to $S$. acidiscabies, allowing $S$. acidiscabies to become a plant pathogen, and this event became evident when seed treatment practices changed.

Streptomyces species from Japan. Although S. scabies is an important pathogen of potato in Japan, another Streptomyces species pathogenic on potato has been described from the island of Hokkaido $(67,68)$. This species has a wide host range among root crops and produces symptoms like those of $S$. scabies. This recently described species is distinctly different from both $S$. acidiscabies and $S$. scabies based on ribosomal DNA sequence comparisons and morphological characteristics. Strains have smooth gray spores in flexuous spore chains, lack melanin or other diffusible pigment production, and use all of the ISP sugars. This Streptomyces species appears to have evolved in a production system in which potato and sugar beets, both good hosts for $S$. scabies, are grown in rotation. Wastes from sugar beet processing plants are routinely applied to fields, providing an excellent mechanism for distribution of inoculum throughout the production area.

\section{Superficial \\ Potato Scab Diseases}

A number of Streptomyces species have been reported to cause superficial symptoms on potato tubers (Fig. 2A), variously described as russet, netted, or turtle back scab. These symptoms differ from those produced by $S$. scabies in that lesions on the potato tuber surface are necrotic and rough in texture, but never raised or pitted. Descriptions of russet and netted scab symptoms and the Streptomyces strains associated with these diseases suggest a varied etiology. Although weakly virulent strains of $S$. scabies can cause superficial lesions on tubers (50), other species, including $S$. aureofaciens and $S$. griseus, are also responsible for superficial scab lesions $(12,15)$.

Streptomyces species that cause netted scab. Netted scab of potato has been reported in the Netherlands, Sweden, Denmark, Norway, Switzerland, and elsewhere in Europe $(3,62)$. The tuber symptoms are superficial, brown lesions that have a distinct netted pattern (Fig. 5). A distinguish- ing and important feature of netted scab is necrosis of all underground parts of the potato plant, including roots $(3,62)$. Severe fibrous root necrosis, associated with netted scab, can result in significant yield losses. S. scabies does not cause root necrosis of potato plants or yield losses (1) under commercial conditions. In addition, while common scab of potato is suppressed by high soil moisture and low temperature, netted scab is most severe under these conditions (5). Evidently, this is the reason that netted scab is economically important in the cool, northern production areas of Europe. Nitrate fertilizers, particularly calcium nitrate, increase the severity of netted scab in comparison to ammonium nitrogen sources (4).
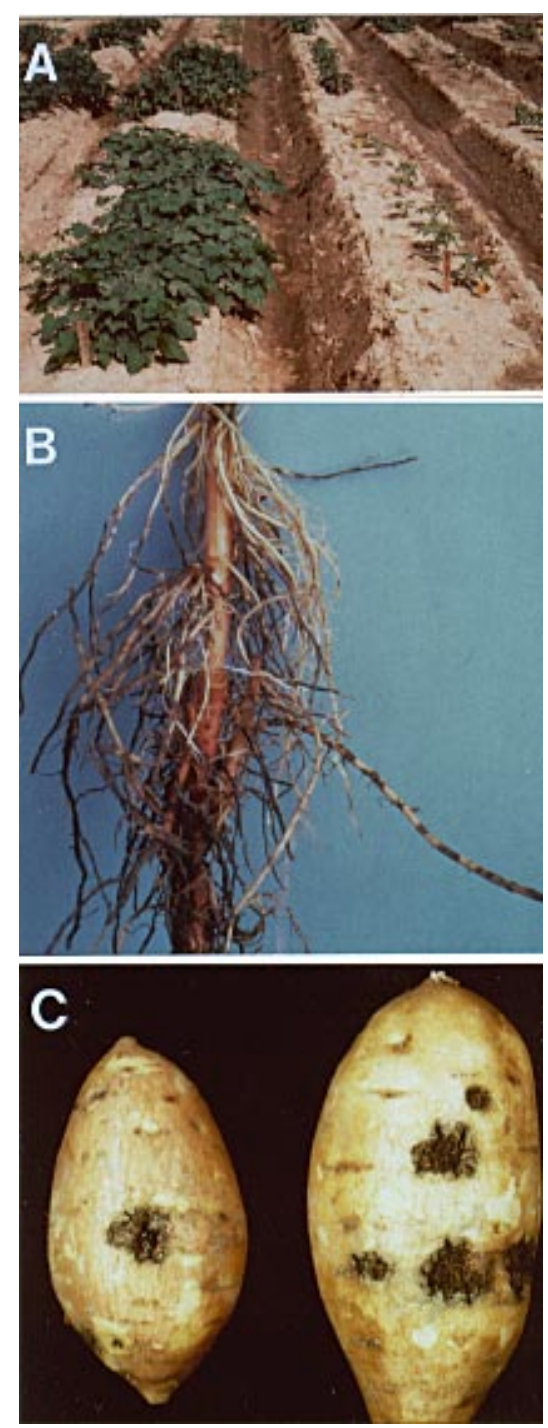

Fig. 6. Soil rot of sweet potato caused by Streptomyces ipomoeae. (A) Fibrous root rot causes a reduction in plant stand and vine growth in susceptible (right) compared with resistant (left) cultivars (courtesy C. A. Clark, Louisiana State University, Baton Rouge). Infection of (B) fibrous and (C) storage roots causes tissue necrosis and results in yield loss (courtesy W. J. Martin). 
Some cultivars of potato are immune to netted scab. Disease resistance is expressed in both the tubers and the roots (62). Interestingly, resistance to the netted scab pathogens is not correlated with resistance to $S$. scabies. The potato cultivar Green Mountain is very susceptible to $S$. scabies infection but highly resistant to netted scab, suggesting that pathogenicity determinants possessed by the Streptomyces species that cause netted scab differ from those of $S$. scabies. Alternatively, differential inhibition of, or resistance to, the two pathogenic species by host cultivars may play a role.

Streptomyces species that cause russet scab. As with netted scab, russet scab is characterized by superficial lesions on potato that are limited to the tuber periderm (20). However, russet scab lesions are not regular in their pattern and are not associated with root necrosis. Presumably because of the lack of root infection, russet scab does not affect potato yields. Therefore, the economic losses associated with the disease are due to reduced marketability of tubers. Prior to 1986, russet scab had been reported only from North America. However, the disease is now known to occur in Japan (56).

Only a very limited amount of research has been conducted on russet scab. Harrison first reported russet scab in North America in 1962 and attributed the disease to a Streptomyces species (20). Unfortunately, little characterization of the isolates was done and type cultures were not maintained. The strains lacked melanin production and produced only sparse aerial mycelium on cream-colored substrate mycelium. Differences in characteristics among the groups of russet scab-causing strains reported from the United States (20), Canada (15), and Japan (56) indicate that this disease is actually caused by a number of taxonomically distinct species. Russet scab did increase in severity in response to high soil moisture, as does netted scab. However, the optimum temperature for russet scab was higher than for netted scab and similar to that reported for common scab. Resistance of potato cultivars to russet scab was quantitative and incomplete, consistent with erumpent scab diseases and in contrast to netted scab (20). These observations, taken together, strongly suggest that russet, netted, and erumpent scab diseases are caused by different Streptomyces species.

\section{Soil Rot of Sweet Potato}

Soil rot of sweet potato (Ipomoea batatas (L.) Lam.) was first described in 1890, but it was thought to have a fungal etiology until 1929, when the causal agent was identified as an actinomycete and named Actinomyces pox. The pathogen was renamed Actinomyces ipomoeae by Person and Martin in 1940 (57) and is currently known as $S$. ipomoeae based on a description by Waksman and Henrici in 1948 (71). This species uses most ISP sugars but does not utilize galacturonic acid. It produces smooth blue spores borne in chains with open loops, spirals, or in spiral globose structures resembling sporangia (9).

The pathogen infects both the fibrous roots and the fleshy storage roots of sweet potato (Fig. 6). Infected fibrous roots become necrotic and die, resulting in reduced plant stand, vine growth, and yields. Necrotic lesions on fleshy roots reduce their marketability. The importance of fibrous root infection to disease losses and the ability of $S$. ipomoeae to directly penetrate fibrous roots (10) is in contrast to the pathology of $S$. scabies on potato. It is interesting that both the netted scab pathogens and $S$. ipomoeae cause extensive root rot but neither causes erumpent lesions.

Disease losses are highest in dry years and in soils with a $\mathrm{pH}$ above 5.2, conditions that also increase losses to $S$. scabies on potato. In contrast to common scab of potato, resistant sweet potato cultivars provide practical levels of soil rot control $(11,59)$. Irrigation, sulfur application, and fumigation can all reduce losses to soil rot (60). Other commercially important hosts for S. ipomoeae have not been reported, but roots of several species of morning glory, including Ipomoea hederacea, are susceptible (11).

\section{Root Tumor of Cucurbits}

Root tumor of melon was first recognized on melons in 1982 on the island of Kyushu in Japan $(35,54)$. The disease is characterized by large galls on fibrous roots and a reduction in plant growth and wilting, indicating reduced root function (Fig. 7). Subsequently, root tumor was found on cucumber in the same region of Japan. The symptoms of this disease are unlike those previously attributed to other Streptomyces species, and their morphological similarity to galls caused by Agro-
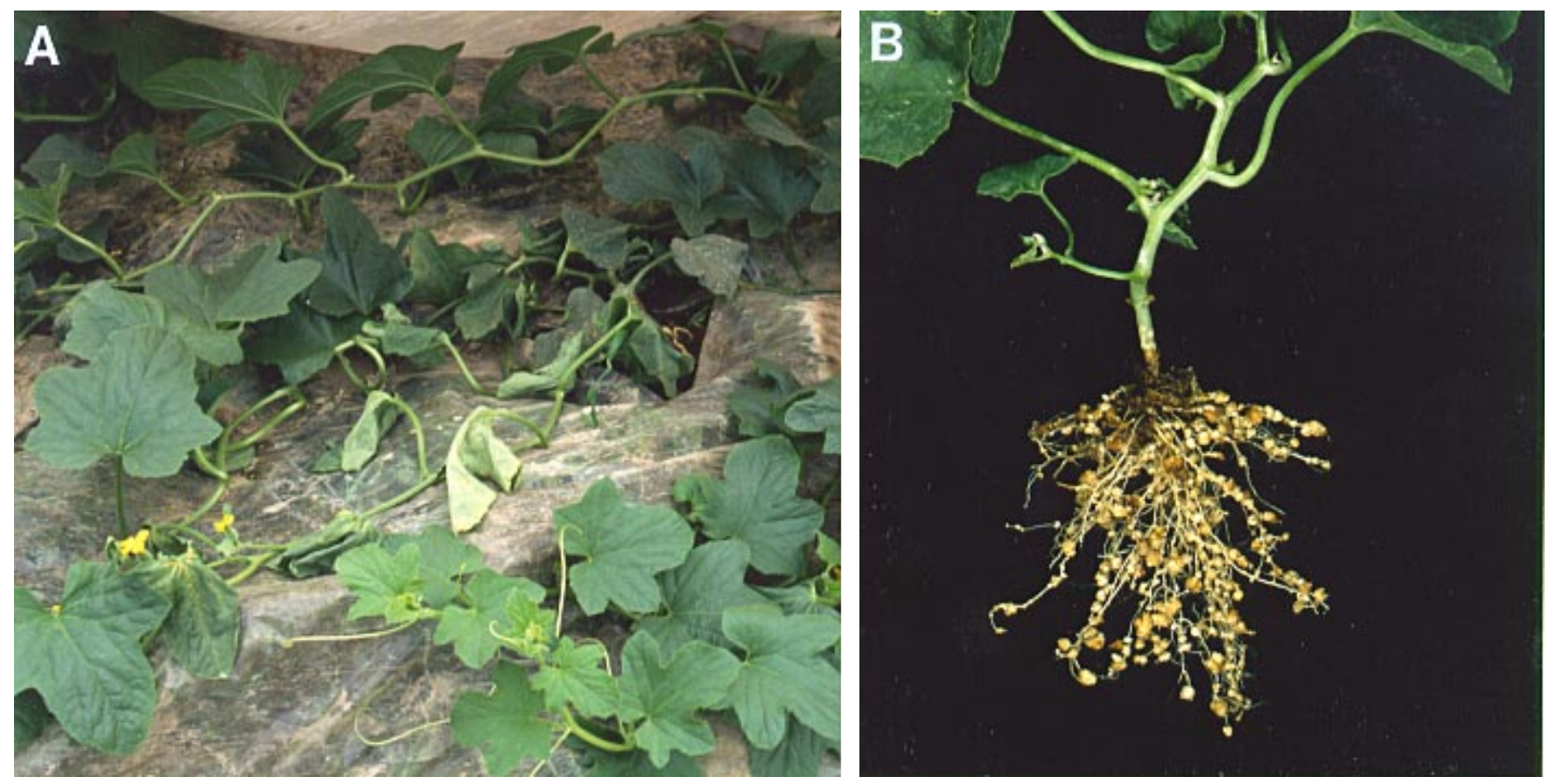

Fig. 7. A Streptomyces species recently identified from Japan causes root tumor of melon. Aboveground symptoms include (A) reduction in plant growth and wilting of vines that result from (B) galling on fibrous roots (courtesy of M. Yoshida, Kyushu Tokai University, Japan). 
bacterium tumefaciens and Pseudomonas savastanoi suggests the involvement of plant growth regulators. The Streptomyces species that causes root tumor of melon is present only in the external cells of the galls. Cells in the interior of the tumor are not infected. Increased cell division or enlargement was suggested to be due to a physiologically active substance produced by the pathogen (26).

The Streptomyces species that causes root tumor is unrelated to previously described plant-pathogenic species based on morphological and physiological characteristics (72). It uses a wide variety of carbon sources, but not D-mannitol, D-sorbitol, salicin, or cellulose. This pathogen produces yellow-brown substrate mycelium and lacks melanoid pigment production. It possesses smooth gray spores that are borne in chains, with an open loop or hook at the end, and pseudosporangia (73).

\section{Phytotoxin Production and Pathogenicity}

Speculation about the involvement of a phytotoxin in potato scab caused by $S$. scabies dates back to $1926(16,25,61,64)$. However, it was not until 1989 that phytotoxic compounds that could reproduce the early symptoms of $S$. scabies on immature potato tubers $(6,43)$ were isolated and identified (34). These phytotoxins, named thaxtomins, were structurally defined by spectroscopic methods and partial synthesis as unique 4-nitroindol-3-yl containing dioxopiperazines (Fig. 8). The symptoms elicited in aseptically cultured potato tubers by $S$. scabies did not differ from those produced by thaxtomins, suggesting that these phytotoxins might be responsible for pathogenicity of this species on potato tubers (44).

Thaxtomin A (compound 1, Fig. 8) is the predominant phytotoxin produced by both $S$. scabies and $S$. acidiscabies in potato tuber tissue, although minor amounts of 10 other related compounds have been isolated and characterized $(28,31,33)$. The thaxtomin structures are unique among microbially produced phytotoxins, and the mechanisms by which these compounds affect plant cells are not known. Elimination of the nitro group, movement of the 4-nitro group to the 5, 6, or 7 positions of the indole ring, replacement of the phenyl side chain, or conversion to a D,L configuration resulted in a complete loss of phytotoxicity to potato tubers (29). Therefore, the 4-nitrotryptophan and phenylalanine groups linked in an L,L-configured cyclodipeptide are required for phytotoxicity.

The hypothesis that thaxtomin production is responsible for pathogenicity on potato predicts that there will be a perfect correlation between thaxtomin production and pathogenicity among Streptomyces strains that infect potato tubers. This prediction held true in a study of 37 isolates obtained from scab-infected potato tubers representative of six sampling areas in eastern and central Canada and five ATCC Streptomyces strains (32). Subsequently, the survey was extended to other sites throughout North America, Europe, and Australia with comparable results $(28,33)$. All pathogenic isolates included in this study produced typical erumpent lesions rather than russet or netted scab symptoms. Interestingly, $S$. ipomoeae produces thaxtomin C (compound 3, Fig. 8) (31), a compound also produced by $S$. scabies and $S$. acidiscabies. Production of thaxtomin $\mathrm{C}$ is correlated with pathogenicity on sweet potato among strains of $S$. ipomoeae as well. All of this evidence points to an important role for thaxtomins in production of plant disease by some Streptomyces species.

To date, no isotope incorporation studies have been carried out to help detail biosynthesis of the thaxtomins. However, the opportune finding that $S$. scabies and $S$. acidiscabies could be induced to generate the phytotoxins in vitro $(2,50)$ provided an improved venue for identifying biosynthetic intermediates. A probable sequence of events, based on in vitro product analysis $(2,27,28)$, projects the condensation of N-methyl-4-nitrotryptophan with phenylalanine to produce 12-N-methylcyclo-(L-4nitrotryptophyl-L-phenylalanyl)

(compound 8, Fig. 8), a logical precursor for the synthesis of all other thaxtomins presently identifed in association with $S$. scabies (28).

Since the production of organic compounds containing nitro $\left(\mathrm{NO}_{2}\right)$ groups is a relatively unusual occurrence in nature, only a limited number of investigations detailing the biosynthetic origins of the nitro group have been done. In all but one of these examples, it has been demonstrated that the nitro group is derived from

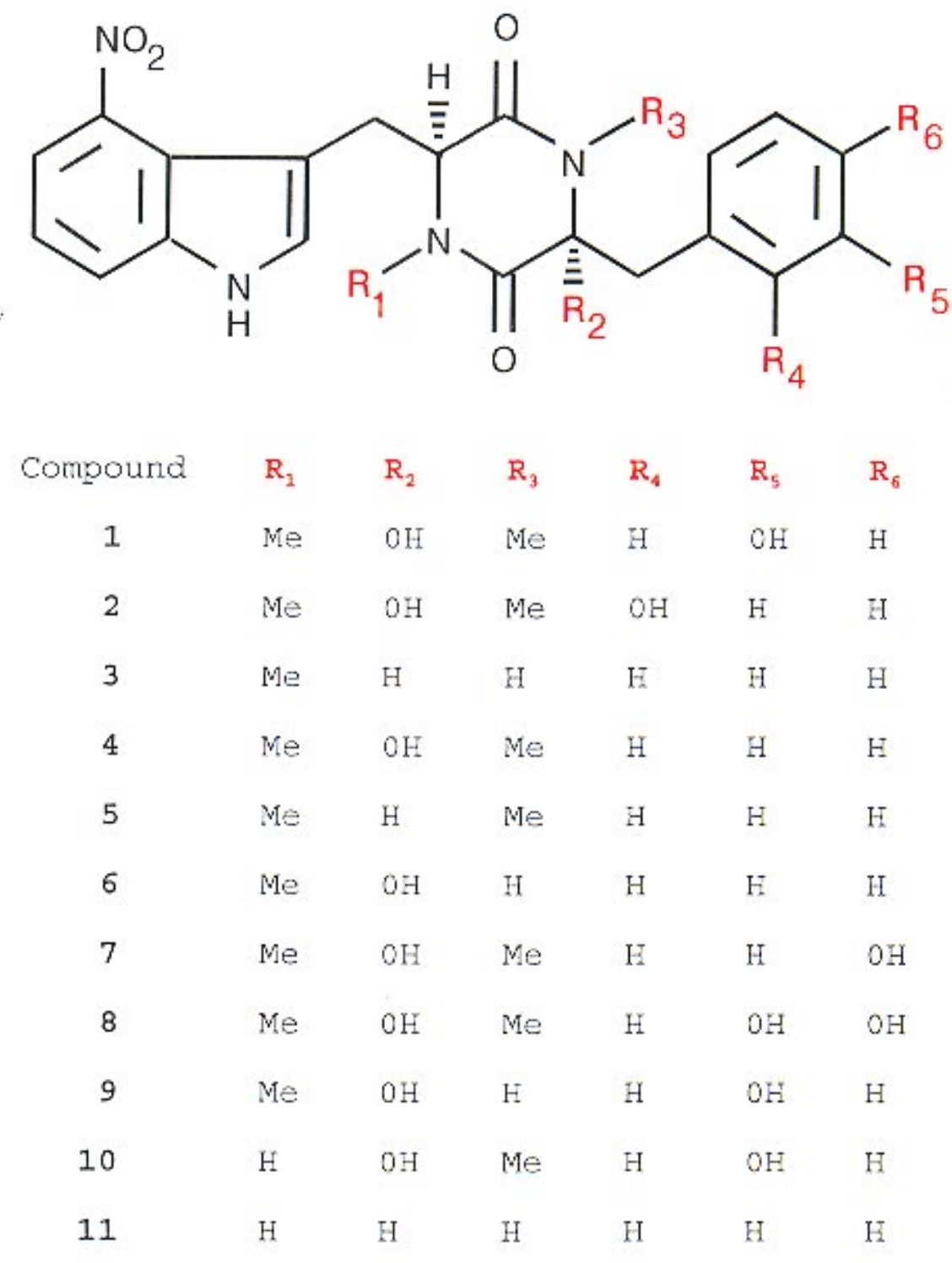

Fig. 8. Structures of thaxtomins produced by plant-pathogenic species of Streptomyces. Thaxtomin A (compound no. 1) is the most abundant of these phytotoxins produced by $S$. scabies in potato tissue. Thaxtomin C (compound no. 3 ) is produced by S. ipomoeae. 
the oxidation of an amino group rather than by direct nitration (8). A likely nitration stage in production of the thaxtomins by $S$. scabies has been identified; i.e., nitration of the tryptophan indole moiety appears to precede formation of the diketopiperazine ring (27). Whether nitration occurs directly or by oxidation of a 4-aminotryptophan precursor has yet to be determined.

\section{Seedling Pathogenicity}

S. scabies (45) and S. acidiscabies (51) cause disease on seedlings of monocot and dicot plants in laboratory studies (Fig. 9). Disease symptoms include reduction of shoot and root length, radial swelling, and tissue chlorosis and necrosis. Seedling pathogenicity appears to be mediated by thaxtomin A production. This toxin also causes a reduction in seedling growth and dramatic radial swelling of roots and shoots of seedlings (45). Radial swelling is due to dramatic cell hypertrophy (Fig. 10), which also can occur on seedling cotyledons. Cell hypertrophy and stunting occur at thaxtomin A concentrations below 1.0 $\mu \mathrm{M}$ (Fig. 11), indicating that thaxtomin A has plant growth regulator effects. At higher concentrations, thaxtomin A kills seedlings, prohibiting plant cell growth and hypertrophy. Since both monocot and dicot seedlings are affected by the toxin, it appears to have a conserved target in plant cells. This target evidently is not conserved in fungi or bacteria, as these organisms are not affected by thaxtomin A (7). The range
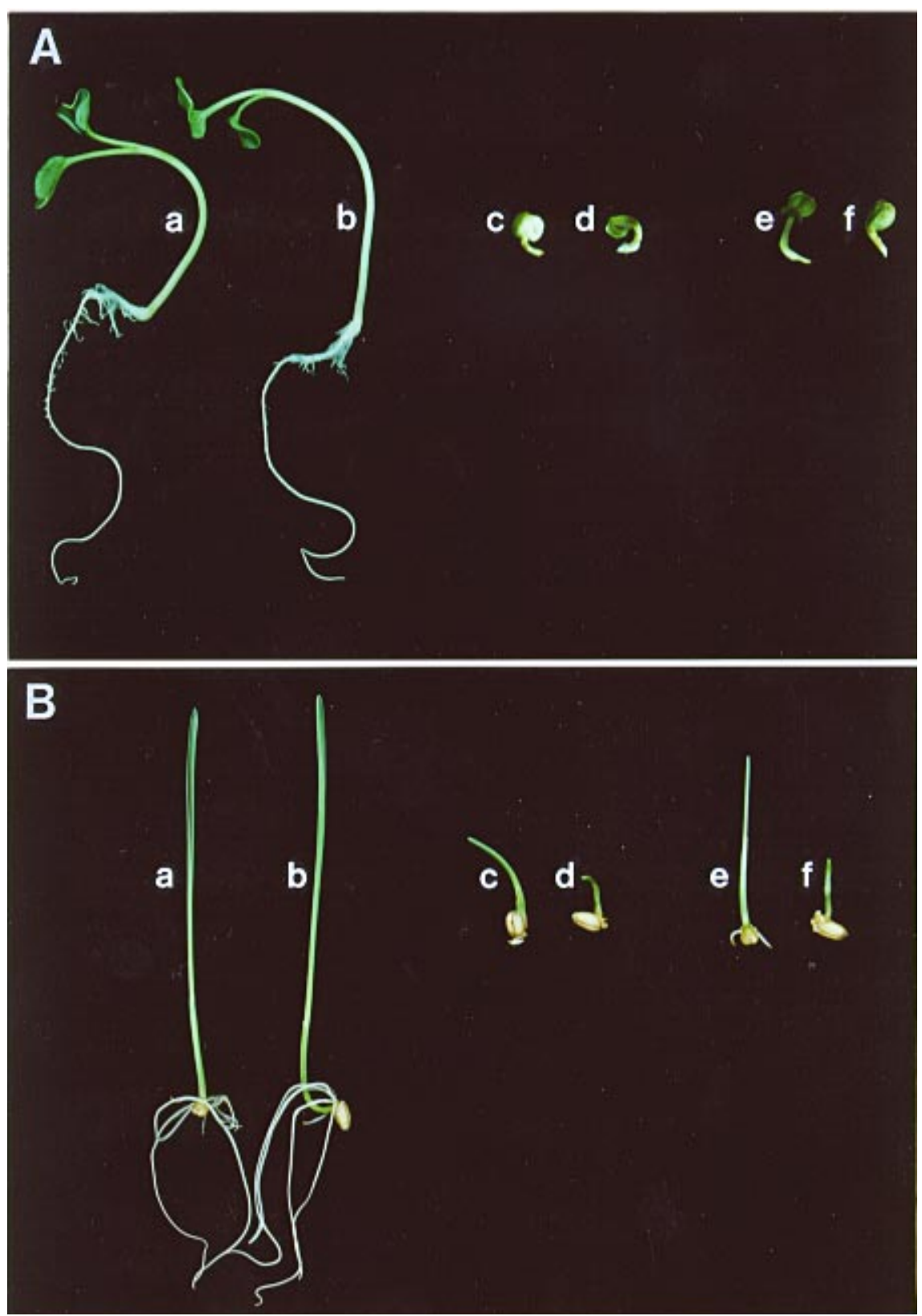

Fig. 9. Symptoms caused by two strains each of Streptomyces scabies and S. acidiscabies on (A) radish and (B) wheat seedlings. Germinated seeds were not treated (a), treated with sterile media (b), or inoculated with S. scabies strains 87-22 (c) and 84-34 (d) or S. acidiscabies strains 84-110 (e) or 84-104 (f).

of symptoms produced by $S$. scabies on potato tubers is analogous to the range of symptoms produced by thaxtomin $\mathrm{A}$ on plant seedlings. Erumpent lesions on potato tubers result from cell hypertrophy (Fig. 12), while toxin-induced cell death likely results in pitted lesions. Therefore, lesion type may be a function of thaxtomin concentration at the infection site. It is also interesting to note that seedlings, like potato tubers, appear to become more resistant to thaxtomin A as they mature.

Seedling pathogenicity by $S$. scabies was first described by Hooker and Kent (24). Although Hooker demonstrated seedling infection when S. scabies was introduced into autoclaved soil (22), Streptomyces species have not been described as a cause of seedling disease in any crop production system. The commercial importance of seedling infection may need to be reexamined, but for the time being, it appears that seedling infection by Streptomyces species does not have a direct impact
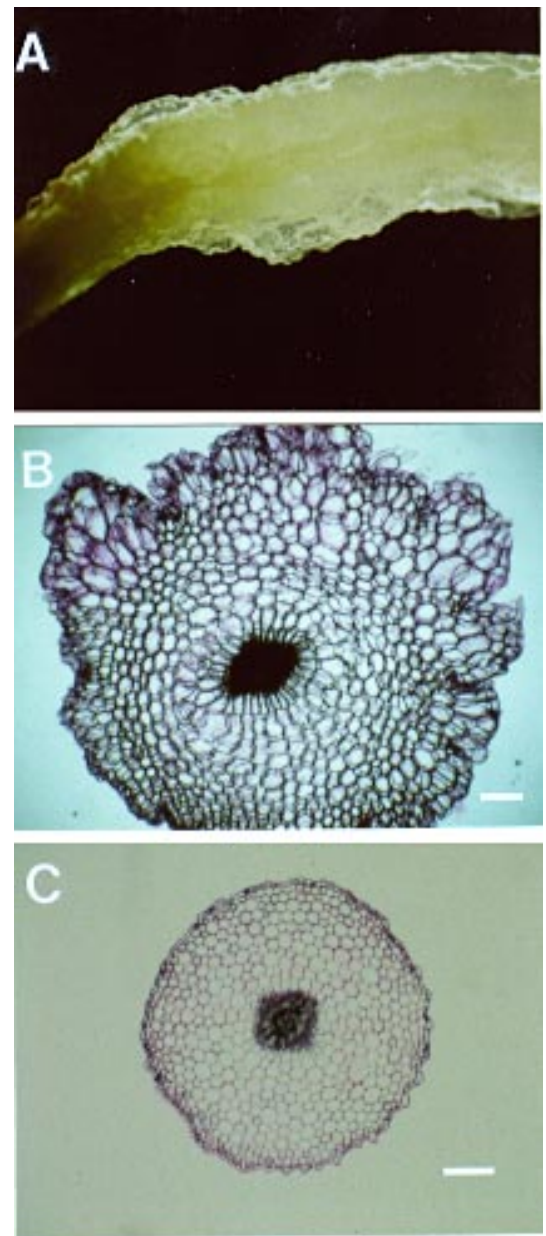

Fig. 10. Dramatic cell hypertrophy on the hypocotyl of a radish seedling that was treated with thaxtomin A. Germinated seeds were incubated on agar containing ( $A$ and $B$ ) $0.075 \mu \mathrm{M}$ or (C) unamended agar for approximately 7 days before examination. Cross sections B and $C$ were approximately $150 \mu \mathrm{m}$ thick and were stained with toluidine blue. Scale bars represent $200 \mu \mathrm{m}$. 
on agriculture. On the other hand, seedling infection may be important for survival of pathogenic Streptomyces species in soil and could explain the many observations of potato scab occurring in soils that were not previously cropped to potato. The role of seedling infection on pathogen ecology may merit further study.

\section{Phylogeny of}

\section{Plant-Pathogenic Streptomyces}

It is interesting to consider the evolution of pathogenicity within the genus Streptomyces. Plant-pathogenic species are diverse in morphological and physiological characteristics, as described previously, and in cellular fatty acid composition (55). These results suggest that plant pathogenic species are not closely related. DNA-DNA hybridization data support these results. Pairwise hybridizations of $S$. scabies and $S$. acidiscabies strains did not exceed $20 \%$ in any comparison (21). Another study demonstrated that $S$. ipomoeae is not closely related to either S. scabies $(39 \%$ DNA relatedness), S. acidiscabies (17\% DNA relatedness), or nonpathogenic Streptomyces species $(37,38)$. A phylogenetic tree constructed on the basis of 16S rRNA sequence data showed that the Streptomyces species that cause potato scab, including $S$. acidiscabies, $S$. scabies, and the phenotypically distinct species from Japan that produces erumpent lesions, comprise unique branches (67). Similarity of $16 \mathrm{~S}$ rRNA sequences of pathogenic and nonpathogenic Streptomyces species indicated that $S$. scabies was more closely related to several saprophytic species in the Diastato- chromogenes group of Elesawy and Szabo (14) than to other pathogenic species. The authors of this study (67) concluded that plant pathogenicity developed independently in these three Streptomyces species. It is also possible that genes conferring pathogenicity were transferred among Streptomyces species.

Interestingly, DNA-DNA hybridization data indicate that while $S$. acidiscabies (21) and $S$. ipomoeae (38) are well-defined species, some strains of S. scabies (21) have much lower DNA relatedness than expected $(<25 \%)$. Cellular fatty acid analysis also suggested that $S$. scabies strains could be divided into two subgroups, although these appeared to be closely related (55). In contrast, data on $16 \mathrm{~S}$ rDNA sequences indicated that $S$. scabies strains from the United States, Hungary, and Japan were 99.9 to $100.0 \%$ similar (67).

It appears that plant pathogenicity arose more than once within the genus Streptomyces or that genes for pathogenicity were horizontally transferred among genetically distinct strains. S. acidiscabies, S. scabies (50), and the Streptomyces species from Japan, represented by strain 91-Sy-13, produce essentially identical symptoms on potato tubers and synthesize thaxtomin A (R. A. Bukhalid and R. Loria, unpublished). Both $S$. acidiscabies and the Streptomyces species from Japan (67) were described relatively recently, and both were obtained from lesions on potato tubers grown in soils in which $S$. scabies was well established. It is possible that genes for thaxtomin A biosynthesis were transferred from $S$. scabies to both $S$. acidiscabies and the Streptomyces species repre- sented by strain 91-Sy-13. Plant pathogenicity and thaxtomin production may have evolved independently in $S$. ipomoeae, as this species only produces thaxtomin C (compound 3, Fig. 8) and is not a potato pathogen under natural conditions. Data on toxin production in culture and putative precursors for thaxtomins produced by $S$. scabies and $S$. ipomoeae also indicate that there may be differences in the thaxtomin biosynthetic pathway in these species $(27,31)$.

\section{Knowledge Gaps and Prospective Application}

Plant pathogenicity among the most economically important species of Streptomyces appears to be mediated by the production of thaxtomins. Certainly, toxin production is widespread among plantpathogenic Streptomyces species, and the effects of the thaxtomins are similar to the symptoms produced by these species on host plants. Definitive information on the importance of these compounds in the establishment of disease can be obtained through cloning and manipulation of the genes in the thaxtomin biosynthetic pathway. Mutation of the thaxtomin biosynthetic genes in pathogenic Streptomyces strains and cloning and expression of these genes in nonpathogenic strains will allow us to determine whether thaxtomin production is both necessary and sufficient for plant pathogenicity. Sequence analysis of the genes in the thaxtomin biosynthetic pathway will yield information on the evolution of these genes and will deter-
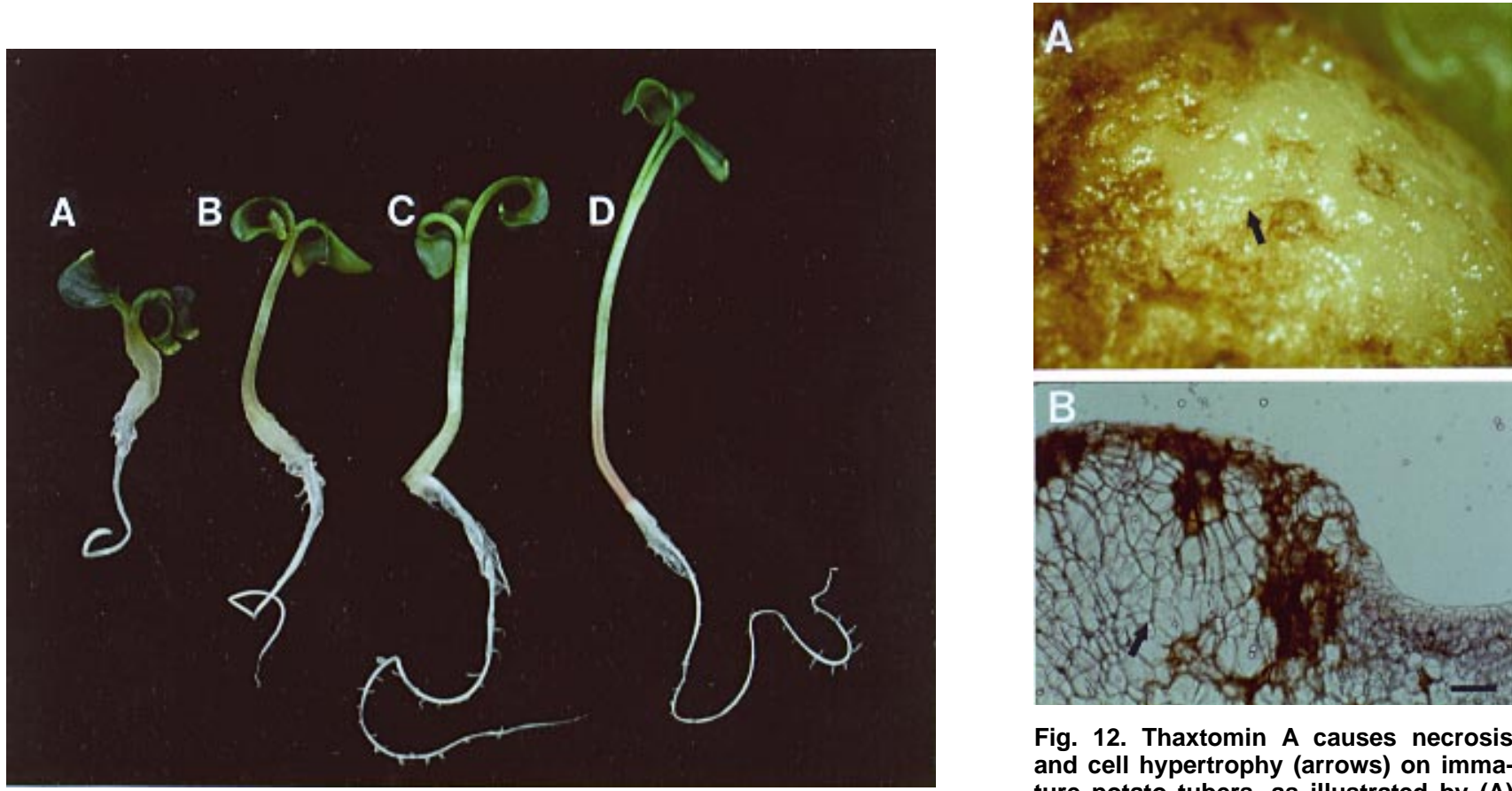

Fig. 11. Thaxtomin A causes stunting and hypertrophy of seedlings at very low concentrations. Germinated radish seeds were incubated on agar containing (A) $0.1 \mu \mathrm{M}$, (B) $0.075 \mu \mathrm{M}$, (C) $0.05 \mu \mathrm{M}$, or (D) $0.0 \mu \mathrm{M}$ thaxtomin A for 7 days.
Fig. 12. Thaxtomin A causes necrosis and cell hypertrophy (arrows) on immature potato tubers, as illustrated by $(A)$ symptoms on the tuber periderm and (B) a cross section through affected area on tuber. Scale bar represents $200 \mu \mathrm{m}$.

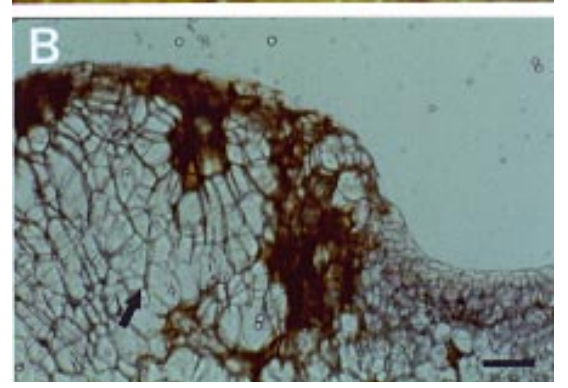


mine whether they have been transferred among diverse Streptomyces species. If phytotoxin production is a pathogenicity determinant in the genus Streptomyces, plant-pathogenic Streptomyces species will be unique among prokaryotic plant pathogens. Other toxins produced by phytopathogenic prokaryotes, such as syringomycin and tabtoxin, are not pathogenicity determinants.

Knowledge about the role of thaxtomins in plant pathogenicity has many applications. If thaxtomin production is a marker for plant pathogenicity among some Streptomyces species, techniques for specific detection of thaxtomin biosynthetic genes can be used for identification of pathogenic strains. This would allow us to answer questions about the effects of soil amendments, crop rotation systems, and edaphic factors on populations of pathogenic strains in vivo. It would also be possible to determine if plant pathogenic Streptomyces strains exist in natural ecosystems, as some data suggest.

Identification of the target for thaxtomins in plant cells may yield strategies for engineering scab resistance in potato and other crops (49). Thaxtomins cause hypertrophy of plant cells at nanomolar concentrations and cell death at concentrations similar to those found in scab lesions on potato tubers (44). Electron microscopy studies indicate that thaxtomin A causes cell collapse in potato tuber tissue, resulting in an electron-dense mass of cell walls and cytoplasm remnants (66). Since bacterial plant pathogens cannot grow in living plant cells, thaxtomin production may be required for establishment of infection. There is some evidence that these toxins may cause cells to release nutrients (22), allowing population increases at the infection site. Data on the effects of low doses of thaxtomin A on membrane integrity and nutrient release could be very instructive. If production of thaxtomins is necessary for plant infection and colonization, resistance to the toxins may confer resistance to infection by some Streptomyces species.

Evidence for mechanisms of plant pathogenicity, other than thaxtomin production, within the genus Streptomyces is lacking. However, since thaxtomin A appears to have a conserved target in plant cells, the host specificity of the netted scab pathogens suggests that other pathogenicity determinants may exist among Streptomyces species. In addition, the netted scab symptom on potato tubers is not indicative of cell hypertrophy, a symptom produced by thaxtomin A on potato tubers. However, data on production of thaxtomins or related phytotoxins by the netted scab pathogens is not available at this time. Likewise, data on thaxtomin production by the newly characterized Streptomyces species responsible for melon root tumor is necessary for a comprehensive understanding of plant pathogenicity in the genus Streptomyces.

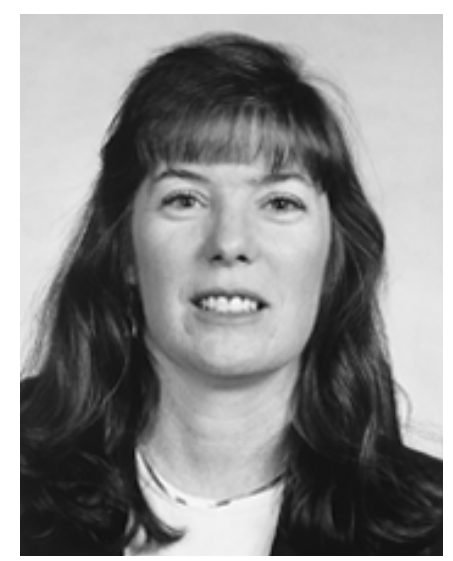

Rosemary Loria

Dr. Loria is a professor in the Department of Plant Pathology at Cornell University. She received her M.S. in 1977 and her Ph.D. in 1980 from the Department of Botany and Plant Pathology at Michigan State University and currently has research and extension responsibilities for potato disease management in New York State. She conducts research on soilborne pathogens of potato, including molecular analysis of pathogenicity in the genus Streptomyces and identification of the plant cell target for thaxtomins.

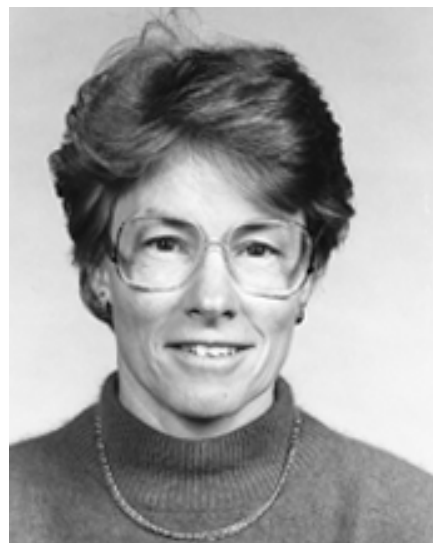

Barbara A. Fry

Ms. Fry has been a research support specialist in the Department of Plant Pathology, Cornell University, since 1994. She received a B.S. in chemistry from Syracuse University in 1968 and an M.S. from the Department of Human Nutrition, Cornell University, in 1970. Her research focuses on identification of the plant cell target for thaxtomin $A$, the phytotoxin produced by pathogenic Streptomyces, and development of techniques for identification of scab-resistant potato germ plasm.

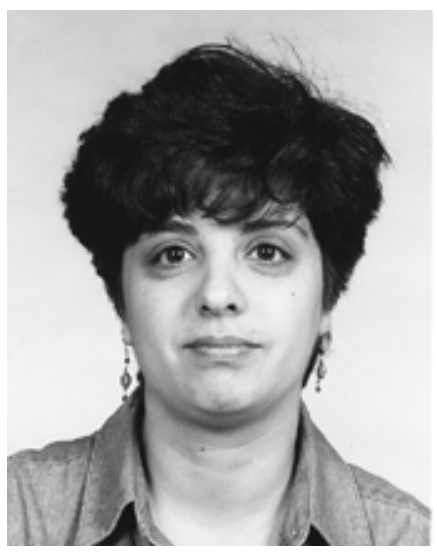

Raghida A. Bukhalid

Dr. Bukhalid is a postdoctoral associate in the Department of Plant $\mathrm{Pa}$ thology at Cornell University. She received her B.S. in agriculture in 1985 and her M.S. in plant pathology in 1988 from the American University of Beirut, Lebanon. In 1996, she obtained her Ph.D. in plant pathology from Cornell University. Her work focuses on the molecular characterization of plant pathogenicity in Streptomyces species and genetic diversity among the plant-pathogenic species of this genus.

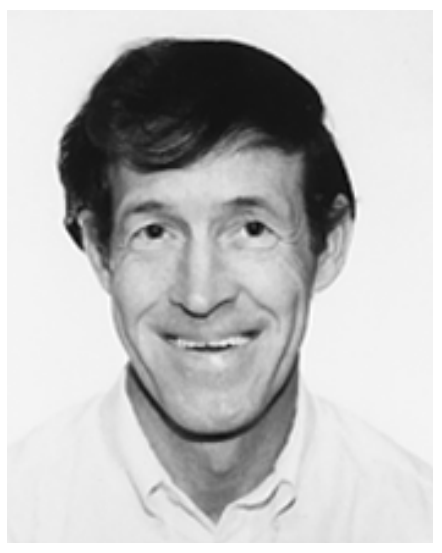

Russell R. King

Dr. King is a senior research scientist at the Agriculture and Agri-Food Canada Research Centre, Fredericton, New Brunswick. He is also an honorary research associate at the University of New Brunswick, Fredericton. Dr. King received his B.Sc. in chemistry from Carleton University, Ottawa, Ontario, his M.Sc. in organic chemistry also from Carleton University, and his Ph.D. in pharmaceutical chemistry from the University of London. Prior to joining Agriculture and Agri-Food Canada in 1975, he held National Research Council postdoctoral fellowships in carbohydrate chemistry at Trent University, Peterboro, Ontario, and at the National Research Council biological division labs in Ottawa. His present research activities are focused primarily on pest management concerns related to the potato crop. 


\section{Literature Cited}

1. Adams, M. J., and Hide, G. A. 1981. Effects of common scab (Streptomyces scabies) on potatoes. Ann. Appl. Biol. 98:211-216.

2. Babcock, M. J., Eckwall, E. C., and Schottel, J. L. 1993. Production and regulation of potato-scab-inducing phytotoxins by Streptomyces scabies. J. Gen. Microbiol. 139:15791586.

3. Bang, H. 1979. Studies on potato russet scab. I. A characterization of different isolates from northern Sweden. Acta Agric. Scand. 29:145150.

4. Bang, H. 1995. Effects of nitrogen sources on development of netted scab. Acta Agric. Scand. Sect. B, Soil Plant Sci. 45:268-270.

5. Bang, H. 1995. Effects of soil conditions on the prevalence of netted scab. Acta Agric. Scand. Sect. B, Soil Plant Sci. 45:271-277.

6. Barker, W. G., and Lawrence, C. H. 1963. Pathogenicity of Streptomyces scabies on potato tubers cultured in vitro. Nature (London) 199:509-510.

7. Bukhalid, R. A. 1996. Investigation of the molecular basis of plant pathogenesis in Streptomyces scabies. Ph.D. thesis. Cornell University, Ithaca, NY

8. Carter, G. T., Nietsche, J. A., Goodman, J. J., Torrey, M. J., Dunne, T. S., Siegel, M. M., and Borders, D. B. 1989. Direct biochemical nitration in the biosynthesis of dioxapyrrolomycin. A unique mechanism for the introduction of nitro groups in microbial products. J. Chem. Soc. Chem. Commun. 1271-1273.

9. Clark, C. A., and Lawrence, A. 1981. Morphology of spore-bearing structures in Streptomyces ipomoea. Can. J. Microbiol. 27:575579.

10. Clark, C. A., and Matthews, S. W. 1987. Histopathology of sweet potato root infection by Streptomyces ipomoea. Phytopathology 77:1418-1423.

11. Clark, C. A., and Moyer, J. W. 1988. Soil rot (pox). Pages 6-9 in: Compendium of Sweet Potato Diseases. American Phytopathological Society, St. Paul, MN

12. Corbaz, R. 1964. Etude des streptomycetes provoquant la gale commune de la pomme de terre. Phytopathol. Z. 51:351-360.

13. DeKlerk, A., McLeod, A., Faurie, R., Swart, W. J., and Denner, F. D. N. 1996. Identification and toxin production of Streptomyces isolates responsible for common scab in the northern Cape Province of South Africa. Proc. Eur. Assoc. Potato Res. Triennial Conf., 13th, Veldhoven, The Netherlands.

14. Elesawy, A. A., and Szabo, I. M. 1979. Isolation and characterization of Streptomyces scabies strains from scab lesions of potato tubers. Designation of the neotype strain of Streptomyces scabies. Acta Microbiol. Acad. Sci. Hung. 26:311-320.

15. Faucher, E., Otrysko, B., Paradis, E., Hodge, N. C., Stall, R. E., and Beaulieu, C. 1993. Characterization of streptomycetes causing russet scab in Quebec. Plant Dis. 77:12171220 .

16. Fellows, H. 1926. Relation of growth in the potato tuber to the potato scab disease. J. Agric. Res. 32:757-781.

17. Goodfellow, M., Williams, S. T., and Mordarski, M. 1988. Actinomycetes in Biotechnology. Academic Press, London.

18. Goth, R. W., Haynes, K. G., and Wilson, D. R. 1993. Evaluation and characterization of advanced potato breeding clones for resistance to scab by cluster analysis. Plant Dis. 77:911914.

19. Gussow, H. T. 1914. The systematic position of the organism of the common potato scab. Science 39:431-432.

20. Harrison, M. D. 1962. Potato russet scab, its cause and factors affecting its development.
Am. Potato J. 39:368-387.

21. Healy, F. G., and Lambert. D. H. 1991. Relationships among Streptomyces spp. causing potato scab. Int. J. Syst. Bacteriol. 41:479482.

22. Hooker, W. J. 1949. Parasitic action of $S$. scabies on roots of seedlings. Phytopathology 39:442-462.

23. Hooker, W. J. 1981. Common scab. Pages 3334 in: Compendium of Potato Diseases. American Phytopathological Society, St. Paul, $\mathrm{MN}$.

24. Hooker, W. J., and Kent, G. C. 1946. Infection studies with Actinomyces scabies. Phytopathology 36:388-389.

25. Jones, A. P. 1931. The histogeny of potato scab. Ann. Appl. Biol. 18:313-333.

26. Kamiunten, H., and Suga, Y. 1989. Electron microscopic observation of the root tumor of melon caused by Streptomyces sp. Ann. Phytopathol. Soc. Jpn. 55:676-679.

27. King, R. R., and Lawrence, C. H. 1995. Characterization of 4-nitrotryptophans associated with the in vitro production of thaxtomin A by Streptomyces scabies. Phytochemistry 40(1): 41-43.

28. King, R. R., and Lawrence, C. H. 1996. Characterization of new thaxtomin A analogs generated in vitro by Streptomyces scabies. J. Agric. Food Chem. 44:1108-1110.

29. King, R. R., Lawrence, C. H., and Calhoun, L. A. 1992. Chemistry of phytotoxins associated with Streptomyces scabies, the causal organism of potato common scab. J. Agric. Food Chem. 40:834-837.

30. King, R. R., Lawrence, C. H., and Calhoun, L. A. 1996. Isolation and identification of pigments generated in vitro by Streptomyces acidiscabies. J. Agric. Food Chem. 44:28492851.

31. King, R. R., Lawrence, C. H., Calhoun, L. A., and Ristaino, J. B. 1994. Isolation and characterization of thaxtomin-type phytotoxins associated with Streptomyces ipomoeae. J. Agric. Food Chem. 42:1791-1794.

32. King, R. R., Lawrence, C. H., and Clark, M. C. 1991. Correlation of phytotoxin production with pathogenicity of Streptomyces scabies isolates from scab infected tubers. J. Am. Potato Assoc. 68:675-680.

33. King, R. R., Lawrence, C. H., and Clark, M. C. 1992. Update on investigations involving phytotoxins associated with Streptomyces scabies. (Abstr.) Am. Potato J. 69:591.

34. King, R. R., Lawrence, C. H., Clark, M. C., and Calhoun, L. A. 1989. Isolation and characterization of phytotoxins associated with Streptomyces scabies. Chem. Commun. 13: 849-850.

35. Kobayashi, K., Yoshida, M., Nakayama, T., and Koga, S. 1987. Root tumor on melon (new name). Ann. Phytopathol. Soc. Jpn. 53:562-565.

36. Kritzman, G., Shani-Cahani, A., Kirshner, B., Riven, Y., Bar, Z., Katan, J., and Grinstein, A. 1996. Pod wart disease of peanut. Phytoparasitica 24:293-304.

37. Labeda, D. P. 1992. DNA-DNA hybridization in the systematics of Streptomyces. Gene 115:249-253.

38. Labeda, D. P., and Lyons, A. J. 1992. DNA relatedness among strains of the sweet potato pathogen Streptomyces ipomoea (Person and Martin 1940) Waksman and Henrici 1948. Appl. Environ. Microbiol. 58:532-535.

39. Lambert, D. H. 1991. Field report of additional hosts for the acid scab pathogen, Streptomyces acidiscabies. Plant Dis. 75:750.

40. Lambert, D. H., and Loria, R. 1989. Streptomyces acidiscabies sp. nov. Int. J. Syst. Bacteriol. 39:393-396.

41. Lambert, D. H., and Loria, R. 1989. Streptomyces scabies sp. nov. nom. rev. Int. J. Syst.
Bacteriol. 39:387-392.

42. Lapwood, D. H., and Hering, T. F. 1970. Soil moisture and the infection of young potato tubers by Streptomyces scabies (common scab). Potato Res. 13:296-304.

43. Lawrence, C. H., and Barker, W. G. 1963. A study of tuberization in the potato, Solanum tuberosum. Am. Potato J. 40:349-356.

44. Lawrence, C. H., Clark, M. C., and King, R. R. 1990. Introduction of common scab symptoms in asceptically cultured potato tubers by the vivotoxin, thaxtomin. Phytopathology 80:606-608.

45. Leiner, R. H., Fry, B. A., Carling, D. E., and Loria, R. 1996. Probable involvement of thaxtomin A in pathogenicity of Streptomyces scabies on seedlings. Phytopathology 86:709713.

46. Lin, Y.-S., Kieser, H. M., Hopwood, D. A., and Chen, C. W. 1993. The chromosomal DNA of Streptomyces lividans 66 is linear. Mol. Microbiol. 10:923-933.

47. Liu, D., Anderson, N. A., and Kinkel, L. L. 1995. Biological control of potato scab in the field with antagonistic Streptomyces scabies. Phytopathology 85:827-831.

48. Lorang, J. M., Anderson, N. A., Lauer, F. I., and Wildun, D. K. 1989. Disease decline in a Minnesota scab plot. Am. Potato J. 66:531.

49. Loria, R. 1994. Common and acid scab of potato: Management, etiology, and potential uses for the phytotoxins produced by Streptomyces species. Pages 149-154 in: Advances in Potato Pest Management. G. W. Zehnder, M. L. Powelson, R. K. Jansson, and K. V. Ramam, eds. American Phytopathological Society, St. Paul, MN

50. Loria, R., Bukhalid, R. A., Creath, R. A., Leiner, R. H., Olivier, M., and Steffens, J. C. 1995. Differential production of thaxtomins by pathogenic Streptomyces species in vitro. Phytopathology 85: 537-541.

51. Loria, R., Grace, E., Bukhalid, R. A., and Fry, B. A. 1996. Streptomyces acidiscabies reduces growth and causes cell hypertrophy and necrosis on monocot and dicot seedlings. (Abstr.) Phytopathology 86:S78.

52. Manzer, F. E., McIntyre, G. A., and Merriam, D. C. 1977. A new potato scab problem in Maine. Univ. Maine Tech. Bull. 85.

53. Murakami, T., Anzai, H., Imai, S., Satoh, A., Nagaoka, K., and Thompson, C. J. 1986. The bialaphos biosynthetic genes of Streptomyces hygroscopicus: Molecular cloning and characterization of the gene cluster. Mol. Gen. Genet. 205:42-50.

54. Nakayama, T. 1985. Root tumor on melon (Abstr.) Ann. Phytopathol. Soc. Jpn. 51:60.

55. Ndowora, T. C. R., Kinkel, L. L., Jones, R. K., and Anderson, N. A. 1996. Fatty acid analysis of pathogenic and suppressive strains of Streptomyces species isolated in Minnesota. Phytopathology 86:138-143.

56. Oniki, M., Suzui, T., Araki, T., Sonoda, R-i. Chiba, T., and Takeda, T. 1986. Causal agent of russet scab of potato. Bull. Natl. Inst. Agro-Environ. Sci. 2:56-59.

57. Person, L. H., and Martin, W. J. 1940. Soil rot of sweet potatoes in Louisiana. Phytopathology 30:913-926.

58. Powelson, M. L., Johnson, K. B., and Rowe, R. C. 1993. Management of diseases caused by soilborne pathogens. Pages 149-158 in: Potato Health Management. R. C. Rowe, ed. American Phytopathological Society, St. Paul, $\mathrm{MN}$.

59. Ristaino, J. B. 1993. Effect of resistance to Streptomyces ipomoeae on disease, yield, and dry matter partitioning in sweetpotato. Plant Dis. 77:193-196.

60. Ristaino, J. B., and Averre, C. W. 1992. Effects of irrigation, sulfur, and fumigation on Streptomyces soil rot and yield components 
in sweetpotato. Phytopathology 82:670-677.

61. Sakai, R., Kawamura, H., Mino, Y., EmamiSaravi, R., and Tanii, A. 1984. Toxin production by Streptomyces spp. associated with scab of potato tuber and sugar beet. I. Effect of carbon and nitrogen sources. Ann. Phytopathol. Soc. Jpn. 50:646.

62. Scholte, K., and Labruyere, R. E. 1985. Netted scab: A new name for an old disease in Europe. Potato Res. 28:443-448.

63. Shirling, E. B., and Gottlieb, D. 1966. Methods for characterization of Streptomyces species. Int. J. Syst. Bacteriol. 16:313-340.

64. Shoemaker, R. A. 1952. Streptomyces scabies and its relationship to common scab of potato. Ph.D. thesis. University of Toronto, Toronto, Ont.

65. Slack, S. A. 1991. A look at potato leafroll virus and potato virus Y: Past, present and future. Badger Common'Tater 43:16-21.

66. Stein, B. D., King, R. R., and Hammerschmidt, R. 1995. Effects of thaxtomin A on the fine structure of potato tubers. Pages 992-993 in: Proc. Microscopy Microanal., 53rd Annu. Meeting.

67. Takeuchi, T., Sawada, H., Tanaka, F., and Matsuda, I. 1996. Phylogenetic analysis of Streptomyces spp. causing potato scab based on $16 \mathrm{~S}$ rRNA sequences. Int. J. Syst. Bacteriol. 46:476-479.

68. Tashiro, N., Miyashita, K., and Suzui, T. 1990. Taxonomic studies on the Streptomyces species, isolated as causal organisms of potato common scab. Ann. Phytopathol. Soc. Jpn. 56:73-82.

69. Thaxter, R. 1891. The potato scab. Conn. Agric. Exp. Stn. Rep. 1890:81-95.

70. Waksman, S. A. 1921. The influence of soil reaction upon the growth of Actinomycetes causing potato scab. Rutgers College Studies 1:61-79.

71. Waksman, S. A., and Henrici, A. T. 1948. Family II. Actinomycetaceae Buchanan and family Streptomycetaceae Wakesman and

Henrici. Pages 892-980 in: Bergey's Manual of Determinative Bacteriology, 6th ed. R. S. Breed, E. G. D. Murray, and A. P. Hitchens, eds. The Williams \& Wilks Co., Baltimore.

72. Yoshida, M., and Kobayashi, K. 1991. Taxonomic characterization of the actinomycete causing root tumor of melon. Ann. Phytopathol. Soc. Jpn. 57:540-548.

73. Yoshida, M., and Kobayashi, K. 1994. Morphogenesis of the pathogenic Streptomyces sp. causing root tumor of melon on the culture medium. Ann. Phytopathol. Soc. Jpn. 60:514522. 